\title{
Accident Analysis and Highway Safety
}

\author{
Noorliyana Omar ${ }^{1, *}$, Joewono Prasetijo ${ }^{1}$, Basil David Daniel ${ }^{1}$, and Mohd Asrul Effendi \\ Abdullah $^{2}$ \\ ${ }^{1}$ Department of Infrastructure and Geomatic Engineering, Universiti Tun Hussein Onn Malaysia, \\ Johor, Malaysia \\ ${ }^{2}$ Department of Statistics and Mathematics, Universiti Tun Hussein Onn Malaysia, Johor, Malaysia
}

\begin{abstract}
Since 2010, Federal Route FT050 (Jalan Batu Pahat-Kluang) has undergone many changes, including the improvement of geometric features (i.e., construction of median, dedicated U-turns and additional lanes) and upgrading the quality of the road surface. Unfortunately, even with these enhancements, accidents continue to occur along this route. This study covered both accident analysis and blackspot study. Accident point weightage was used to identify blackspot locations. The results reveal hazardous road locations and blackspot ranking along the route.
\end{abstract}

\section{Introduction}

Road accidents have been recognised as one of the major problems in the world. In addition, it has major impacts on the society, economy and progress of a country. Road accidents occur when traffic conflicts between vehicular movements which can cause delay and traffic congestion [1]. Rohani [2] mentioned that human error, traffic, vehicle and road conditions, and the surrounding environment have been determined as key factors that influence driving behaviour, which can in turn contribute to road accidents.

Road accidents increase relatively from year to year even though the Malaysian government has carried out many programs. The increment is proportionate to the growth in population, economic development, industrialisation and motorisation in the country [3]. Furthermore, road accidents are the leading cause of death in Malaysia [4].

There are many road accidents reported every day. In 2013, Malaysia recorded 477,204 accidents, which include 6,915 deaths. This resulted in an average of 19 deaths from road accidents every day. Deaths per 10,000 registered vehicles was 2.9, which is high in comparison to developed countries that register 2.0 deaths or less per 10,000 registered vehicles [5].

Fig. 1 shows that in 2013, federal roads in Malaysia had the highest number of road accidents compared to other road categories. Federal Route 50 (FT050) is a four-lane road that runs from Batu Pahat to Kluang (Fig. 2). The road has many access points, almost one per kilometre. The road also has a high density of private driveways and access to properties. 1420 accidents were recorded along this stretch in 2013 alone [6]. So far, at least

*Corresponding author: liyana@uthm.edu.my 
five studies have been conducted along this road [6][7][8][9][10]. Seven locations at FT050 were identified as accident blackspots, which are KM posts 2, 4, 7, 23, 48, 57 and 58 [5]. The accident rate at this road is among the highest compared to other federal roads in the area.

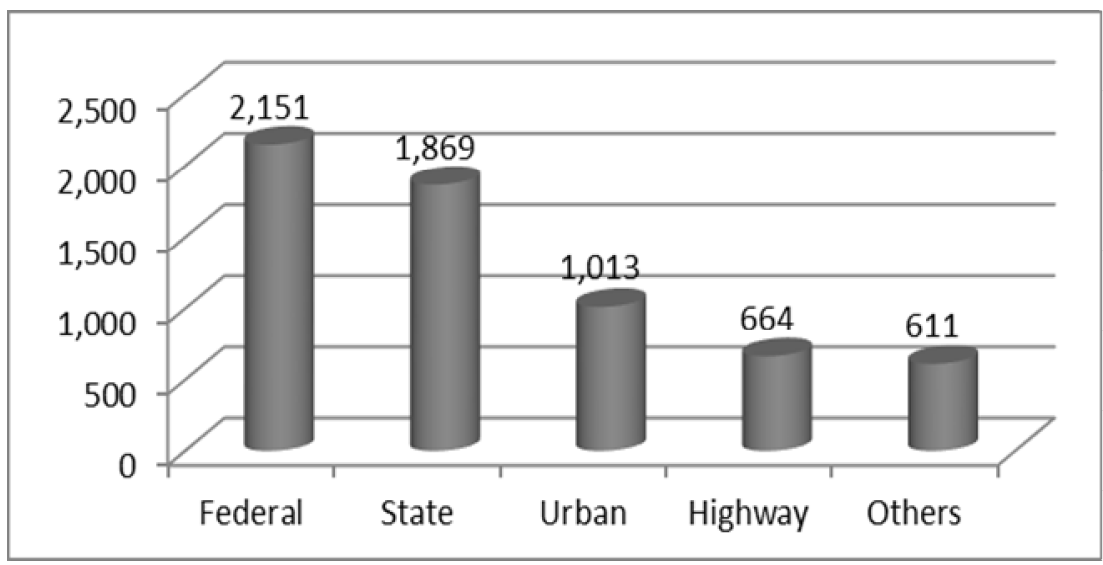

Fig. 1.Accidents based on road types in 2013 [5].

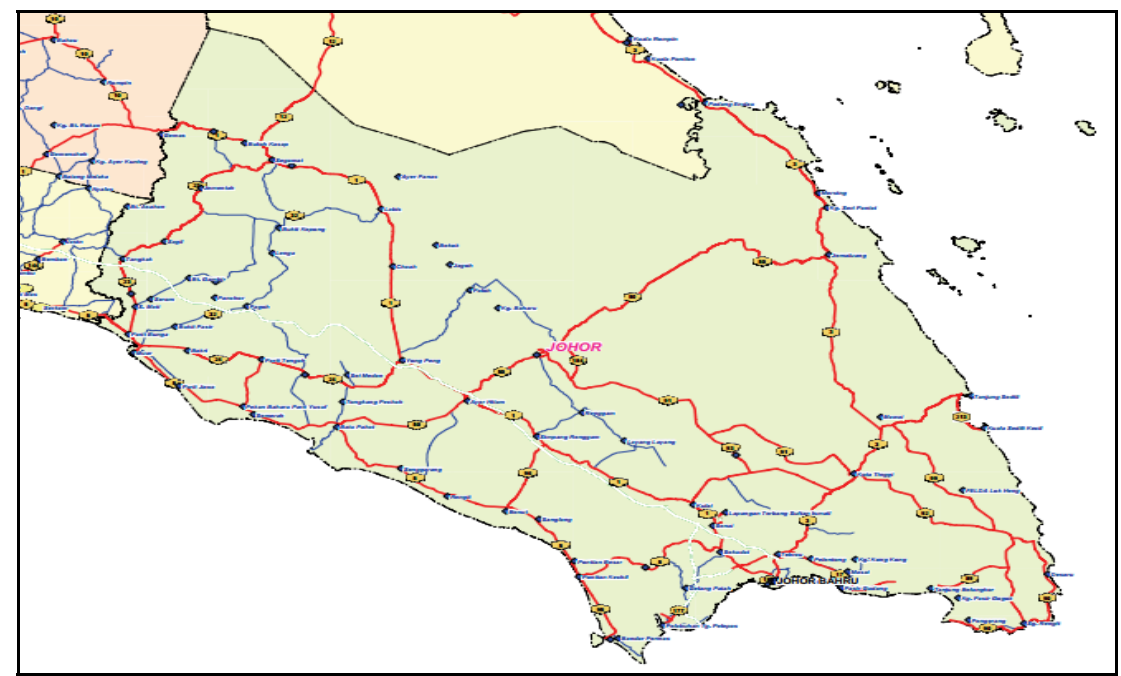

Fig. 2. Study location at Federal Route FT05.

In order to achieve a "developed country" status, Malaysia needs to minimise road accidents and increase the safety level for road users. The Malaysian Institute of Road Safety (MIROS) was established in order to monitor and enhance road safety in Malaysia. It acts as the main organiser in developing young minds and educating people about road safety. In addition, the institute, through their advanced Research and Development unit, focuses on how to minimise road accidents through road standards and design.

The location of this study is along Federal Route 50 (FT050), one of the black spot areas in Johor [11]. Based on the road accident statistics, the accidents involved cars, lorries, bicycles, pedestrians and mostly motorcyclists [8]. 


\section{Aims}

The aim of this study is to analyse the accident data in order to identify blackspots along Federal Route 50.

\section{Method}

The methodology adopted for this study involves identification of the study area, accident data collection from the police station and blackspot identification.

\subsection{Data collection}

Accident data was collected from PDRM covering all police recorded accidents. The data included; number of fatalities, number of seriousness of the injuries (i.e., serious and slight injury) and number of accidents that did not involve any injury. A five-year accident period was used, starting from 2010 until 2014.

\subsection{Analysis of accident data}

The raw data were collected from PDRM as mentioned in section 3.1 and analyzed to determine the accident pattern at the studied area. The analysis consist of accidents severities by year, accidents by section and black spot location.

\subsection{Blackspot identification}

An accident blackspot refers to a section of a road regarded as a high-risk location for vehicle crashes. Identification of accident blackspots was carried out using the accident point weightage method.

The accident point weightage formula was used to determine the ranking of accidents for every kilometre. Each accident severity level has its own weightage. For accidents involving fatalities, the numbers need to be multiplied by 6.0. For serious injury, slight injury and not involving any injury, the numbers need to be multiplied by $3.0,0.8$ and 0.2 , respectively [12]. The equation for the above mentioned method is shown in Equation (1).

$$
A P W=X_{1}(6.0)+X_{2}(3.0)+X_{3}(0.8)+X_{4}(0.2)
$$

where, $X_{1}=$ Number of fatalities, $X_{2}=$ Number of serious injuries, $X_{3}=$ Number of slight injuries, and $X_{4}=$ Number of damages only

\section{Results and analysis}

This study was designed to analyse accident data and identify accident blackspot. The following sections report the results of this study.

\subsection{Accident severity by year}

Data on accident severity was analysed from year 2010-2014. The results can be seen in Fig. 3. 


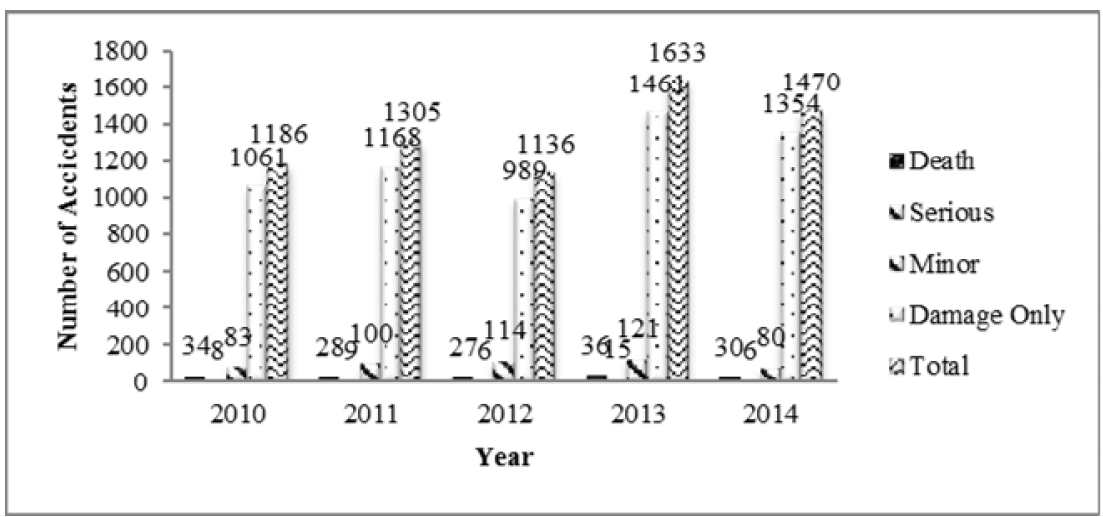

Fig. 3.Accident severity from $2010-2014$.

As observed from Figure 3, the accidents increased from 2010 to 2011 . From only 1186 accidents in 2010, the number increased to 1305 in 2011. In 2012, there was a slight decrease in the number of total accidents. This is because of the upgrading process of this road which causes drivers to decrease their speed along the work zone. However, the total number of accidents increased from 1136 to 1633 from 2012 to 2013. This may be due to a sharp increase in total vehicle registration as reported by the Road Transportation Department (2015) [13]. In 2014, the number of accidents decreased to 1470. The highest number of recorded accidents between 2010 and 2014 occurred in the year 2013, where a total of 1633 accidents were recorded.

\subsection{Accidents by section}

From the accident severity data by year, this study focused on the highest number of accidents based on section location. The results can be seen in Fig. 4.

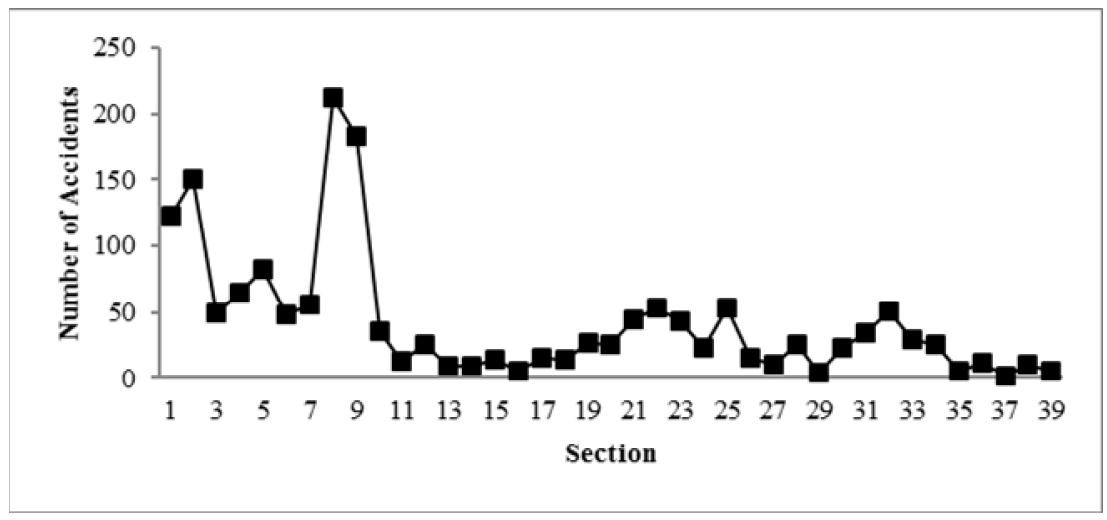

Fig. 4. Total Number of Accidents by Section in 2013.

The highest numbers of accidents was recorded in 2013 at KM 8 (Fig. 4). Land use and vertical alignment are amongst the factors that contribute to this figure. Along this section, there are several buildings such as Pejabat Kaji Cuaca, Maktab Perguruan Tun Hussein Onn and Kolej Vokasional Batu Pahat. The type and functions of buildings along the road have a considerable influence on accident risk [14]. 
The highest number of fatalities occurred in 2010 at KM 10. The high number of fatalities was contributed by two factors, which are land use [14] and road alignment. At this location, there are a number of factories. Furthermore, traffic conflict occurred due to the presence of many access points and road alignment [15].

The highest number of serious accidents occurred in 2013 at KM 9. Since this section is near Pejabat Kaji Cuaca, Maktab Perguruan Tun Hussein Onn and Kolej Vokasional Batu Pahat, the contributing factors to the high accident rate are land use and type of terrain. As mentioned before, type and functions of building along the road has a considerable influence on the accident risk [14].

The highest number of minor accidents was recorded in 2012 at KM 32. The main factor that caused minor accidents is land use. At this location, there are shop lots along the road. More traffic conflict occurred due to the presence of many access points [15].

The highest "damage only" accidents were recorded in 2014 at KM 1. The main factors that caused minor accidents are land use and road alignment (roundabout). At this location, there are roundabouts and shop lots along the road. More traffic conflict occurred due to the presence of many access points and roundabouts [15]. Traffic conflict is "an observable situation in which two or more road users approach each other in space and time for such an extent that there is a risk of collision if their movement remain unchanged" [16].

\subsection{Black spot}

Black Spot is the simplest way of ranking sites and it is recommended to be used in Malaysia [7]. All that is needed to be done is to shortlist the ranking of the accident blackspot area. From the analysis, the ranking shows that the highest Accident Point Weightage value from each section analysis of the traffic accident record by PDRM.

Fig. 5 shows the top ten accident ranking from 2010 to 2014. In 2010 and 2011, Sharp/ROXY factory was placed in the first ranking. As mentioned previously, any accident which occurred along the road was due to land use [14]. Besides that, many pedestrians use this road as reported by $[14,17,18]$.

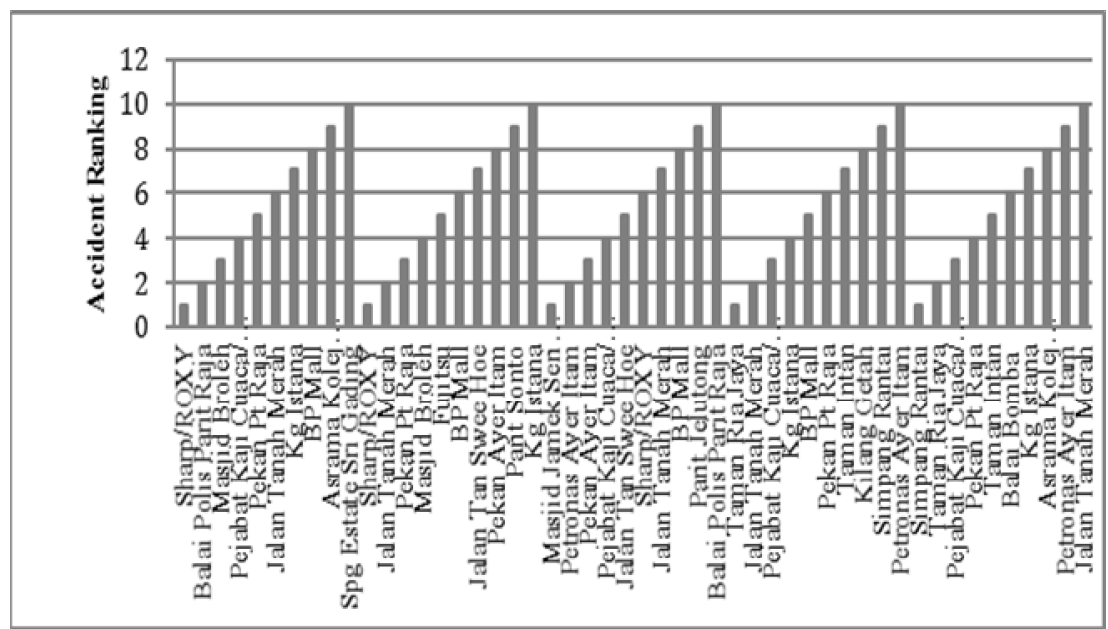

Fig. 5.Accident Ranking by Location from year 2010-2014.

Masjid Jamek Seri Beroleh has the top ranking in 2012. A petrol station is located beside this place. These locations are parallel to this route. There is driveway from the main 
road to this place. Therefore, this situation can create conflict at this access point and affect the number of accidents [17].

In 2013, Taman Ria Jaya was ranked $1^{\text {st }}$. Since this section is near Pejabat Kaji Cuaca, Maktab Perguruan Tun Hussein Onn and Kolej Vokasional Batu Pahat, the contributing factors that make it at the top of the list are land use and type of terrain. Type and functions of building along the road have a considerable influence on the accident risk [14].

Ranked $1^{\text {st }}$ was Simpang Rantai in 2014. This location is an unsignalized intersection with a roundabout thus this section had many traffic conflicts. Traffic control will affect the number of accidents $[17,19,20]$.

\section{Conclusions}

From this accident analysis, the following conclusions can be drawn:

i) Since the upgrade of FT050 in 2010, the number of accidents has increased instead of producing a safer route for the community.

ii) The authorities and government should take this issue seriously and introduce precautionary steps to prevent more accidents from happening along this route.

iii) This study found that accident data fluctuates from year to year.

iv) This study had also established the accident point weightage to rank the accident blackspots along the FT050 stretch (KM1.0 - KM38.0) to determine hazardous road sections.

v) The result shows that KM $1-\mathrm{KM} 10$ and KM $21-\mathrm{KM} 23$ are the most dangerous stretches along FT050. This result was supported by data obtained by the Royal Malaysian Police [5].

vi) Further research should be conducted in order to improve information, safety awareness and propose actions for the public or the authorities.

The authors gratefully acknowledge the Ministry of Higher Education Malaysia (MOHE) for providing financial support for the authors and to Universiti Tun Hussein Onn Malaysia (UTHM) for providing the resources needed to complete this paper.

\section{References}

[1] J. Prasetijo, W. Razzaly, N. Wu, K. Ambak, M.E. Sanik, M.M. Rohani, and H. Ahmad, Capacity Analysis of priority intersections with flare under mixed traffic conditions, Procedia - Soc. Behav. Sci., 138, 660-670 (2014)

[2] M. Rohani, R. Buhari, B.D. Daniel, K. Ambak, N.A. Sukor, and F.S. Asmah, Car driving behaviour on road curves: A study case in Universiti Tun Hussein Onn Malaysia, Appl. Mech. Mater., 10, 990-995, (2015)

[3] W.N.W. Manan, Accident Prediction Model at Un-Signalized Intersections Using Multiple Regression Method, Master Thesis, Universiti Tun Hussein Onn Malaysia, (2011)

[4] J. Prasetijo, S. Nur, F. Mohd, K. Ambak, and B.D. Daniel, Investigation of the impact on different type of toll plaza crash barriers by numerical approach, 11, 3690-3696, (2016)

[5] RMP, Royal Malaysia Police.pdf, (2015)

[6] F. Mustakim, and B. D. Daniel, Accident investigation, blackspot treatment and accident prediction model at federal route FT50 Batu Pahat-Air Hitam, The 4th National Technical Post Graduate Symposium, (2006) 
[7] F. Mustakim, A. Aziz, and A. Samad, Blackspot study and accident prediction model using multiple liner regression, Advancing and Integrating Construction Education, Research and Practice, 121-136 (2008)

[8] A. Raqib, A. Ghani, M.E. Sanik, R. Aida, and M. Mokhtar, Comparison of accident prediction model, Int. Semin. Appl. Sci. Math., (2011)

[9] F. Mustakim, and M. Fujita, Development of accident predictive model for rural roadway, Int. J. of Civil, Archit. Struct. Constr. Eng., 5, 46-51 (2011)

[10]J. Prasetijo, and Z.F. Zainal, Development of continuous speed profile using GPS at Johor Federal Roads F0050, MATEC Web Conf., 24, 0-5 (2016)

[11]B.Y.C. Tan, Batu Pahat district records the highest increase in road accident fatalities, The Star, 23-25, (2012)

[12]B.N.P. Alireza Hadayeghi, and Amer S. Shalaby, TRB 2003 Annual Meeting CDROM Paper revised from original submittal, (2003)

[13]JPJ, Jumlah Pendaftaran Lain-lain Kenderaan Mengikut Tahun.pdf, (2015)

[14]P. Greibe, Accident prediction models for urban roads, Accident Analysis and Prevention, 35, 273-285 (2003)

[15]R. Fu, Y. Guo, W. Yuan, H. Feng, and Y. Ma, The correlation between gradients of descending roads and accident rates, Saf. Sci., 49, 416-423 (2011)

[16]K. El-Basyouny, and T. Sayed, Safety performance functions using traffic conflicts, Saf. Sci., 51, 160-164 (2013)

[17]A. Ahmed, A. F. M. Sadullah, and A. S. Yahya, Accident analysis using count data for unsignalized intersections in Malaysia, Procedia Eng., 77, 45-52 (2014)

[18] M. Simonc, Road accidents in Slovenia involving a pedestrian , cyclist or motorcyclist and a car, Accid. Anal. Prev., 33, 147-156 (2001)

[19] S. Daniels, T. Brijs, E. Nuyts, and G. Wets, Extended prediction models for crashes at roundabouts, Saf. Sci., 49, 198-207 (2011)

[20]B. De Brabander, and L. Vereeck, Safety effects of roundabouts in Flanders: Signal type, speed limits and vulnerable road users., Accid. Anal. Prev., 39, 591-599 (2007) 